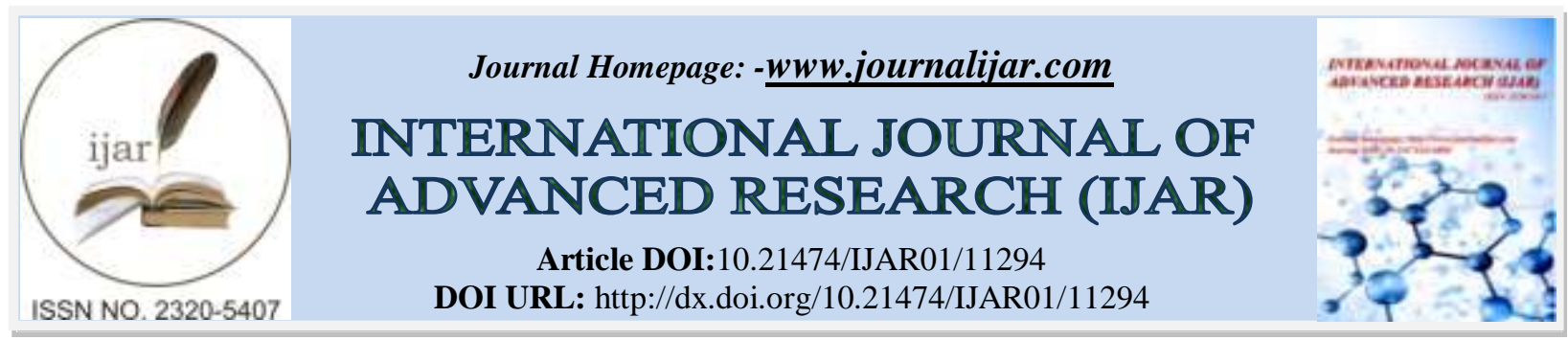

RESEARCH ARTICLE

\title{
STATUS OF ALTERNATIVE LEARNING SYSTEM (ALS) AT THE CITY SCHOOLS DIVISION OF CABUYAO: A BASIS FOR AN IMPROVED PROGRAM IMPLEMENTATION
}

\author{
Roderick O. Delmo ${ }^{1}$ and Alberto D. Yazon ${ }^{2}$ \\ 1. Cabuyao Central School, Department of Education - Cabuyao, City of Cabuyao, Laguna, Philippines. \\ 2. College of Teacher Education, Laguna State Polytechnic University, Los Banos Campus, Los Banos, Laguna, \\ Philippines.
}

\section{Manuscript Info}

...........................

Manuscript History

Received: 05 May 2020

Final Accepted: 10 June 2020

Published: July 2020

Key words:-

Instructional Managers, Life Skills

Values Development, A and E Test

\begin{abstract}
This study was conducted to determine the status of the Alternative Learning System (ALS) at the City Schools Division of Cabuyao, a basis for an improved program implementation. A total of 315 respondents, 159 Accreditation and Equivalency (A \& E) Test passers and 146 non-passers, and 10 ALS Instructional Managers (IMs) participated in the study. The study utilized the descriptive method of research. The statistical treatment included the tabulation of mean, standard deviation, and Pearson Correlation Coefficient to analyze the gathered data. The results revealed that ALS teaching methods, instructional materials and facilities and community support were implemented to a moderate extent and that the instructional managers were highly competent in the implementation of the program. Findings further revealed that both the A \& E passers and non-passers show improvement on their life skills and values development, particularly on their communication skills, scientific and critical thinking skills, mathematical skills, life and career skills, understanding self and society and digital citizenship. This proved that both the passer- and non- passer-respondents considered the ALS implementation an avenue in improving their life skills and values development. The research also found out that the methods of teaching are related to ALS passers' improvement in life and career skills and that community support influences their communication skills. It is suggested that IM's take appropriate steps to strengthen their instructional competence and come up with appropriate pedagogies to produce learners equipped with requisite life skills and steeped with values aligned with the learning strands of the program and that ALS implementers produce modules that are A \& E Test-skills-based, values-laden, localized and contextualized to help both IMS and learners ensure mastery of life skills and values development which may lead to an increased A \& E passing rate.
\end{abstract}

Copy Right, IJAR, 2020,. All rights reserved.
Corresponding Author:- Roderick O. Delmo

Address:- Cabuyao Central School, Department of Education - Cabuyao, City of Cabuyao, Laguna, Philippines. 


\section{Introduction:-}

The 1987 Philippine Constitution provides for the recognition and promotion of other forms of education other than formal education. Article XIV, Section 2, paragraph 1 declares that the State shall establish, maintain and support a complete, adequate and integrated system of education relevant to the needs of the people and society; and paragraph 4 concisely encourages non-formal, informal and indigenous learning systems as well as self-learning, independent and out-of-school study programs particularly those that respond to community needs.

The Department of Education (DepEd) through "Governance of Basic Education Act of 2001" includes Alternative Learning System (ALS) for out-of-school youth and adult learners. This act aims to protect and promote the right of all the citizens to quality basic education and to make such education accessible to all by providing all Filipino children a free and cumpolsary education in the elementary level and free education in the high school level. [1].

The Governance Act for Basic Education otherwise known as the Republic Act 9155 stipulates the establishment of the Alternative Learning System (ALS) to provide out-of-school children, youth and adult learners with basic education regardless of their demographic profile and/or social and economic status.

This is why the Alternative Learning System is a parallel learning system to provide a viable alternative to the existing formal education instruction, encompassing both the non-formal and informal sources of knowledge and skills (Section 12.1 Rule XII, R.A. 9155). Informal education seeks to offer a learning experience that is based on the common needs or interest of an individual or group, whether on civic, spiritual, socio-economic, cultural, and recreational or wellness aspects. Non-formal education, on the other hand, is methodological or structured form of learning that is outside the formal school system.

In comparison to the formal system, Bumanglag[2]said ALS offers more flexible learning when it comes to time, module selection, sequence, place, content and method of learning. Instead of a classroom-based learning, ALS holds classes in what they refer to as a Community Learning Center (CLC) which can just be any space available like barangay hall, chapel, sports center, streets among others.

DepEd Order No. 13, s. 2019 re: Policy Guidelines on the implementation of Enhanced Alternative System 2.0 states that ALS shall provide opportunities for out of school youth and adult (OSYA) learners to develop basic and functional literacy skills and to access equivalent pathways to complete basic education. [3].

With the introduction of the ALS program as an alternative to formal education, out-of-school youth and other adults are given the second chance to their continuing education, thus, improve themselves. However, implementation of the said program should be in harmony with the existing formal education and that the implementation of its policy is well carried out so as not to defeat its very purpose. ALS program implementers must see to it that the program is effectively and efficiently accomplished and implemented.

\section{Materials and Methods:-}

This research work utilized the descriptive correlational design. This was used to describe the variables and the relationship that occur naturally between them (Jackson, 2015)[4]. In this study, the researcher determined the extent of IM's implementation of the Alternative Learning System (ALS) in the City Schools Division of Cabuyao and the learners' improvement in their life skills and values development and the relationship between them.

Moreover, quantitative approach was employed using simple mean, standard deviation, and Pearson correlation coefficient.

The respondents of the study were the ten (10) ALS mobile teachers and instructional managers and the 305 ALS learners during the years 2014 - 2018 composed of 159 A \& E Test passers and 146 non-passers.The researcher considered the stratified random sampling method in choosing the number sample respondents, so that both passers and non-passers would have the equal chances of being considered as respondents. The online sample size calculator was used where the margin of error considered was 5 percent to determine the number of appropriate respondents. This study utilized a survey questionnaire which was derived from the unpublished dissertation of Abastilas[5], Alternative Learning System Program at the Bureau of Jail Management and Penology in Region IVA: An Enhanced Policy Formulation. The same questionnaire was utilized by the teacher-respondents and the ALS 
A \& E Passer- and Non-Passer-respondents. The questionnaire has three parts; Part I is about the extent of ALS implementation in the City of Cabuyao in terms of method of teaching, instructional materials, facilities and equipment, community support and instructional managers' competence. Part 2 of the survey questionnaire was about problems encountered during the implementation of ALS program. On the other hand, part 3 was about the leaners' improvement in their life skills and values development. Questions in the third part are taken from ALS Learning Strand 4 - Life and Career Skills and Learning Strand 5 - Understanding the Self and the Society Checklist.

The instruments used were validated by four (4) experts composed of two (2) ALS implementers, the research adviser and a statistician. Their expertise on the study provided relevant feedback and suggestion to make the sets of questions sound aligned, easy to comprehend for fast and easy transcription of the responses. After pilot testing, the overall reliability coefficient of Cronbach alpha $=0.76$ was obtained which denotes a high reliability index.

\section{Results and Discussion:-}

This part contains the presentation, analyses and interpretation of data gathered from the respondents, how the data were treated to facilitate interpretation and relationship between and among variables in the study.

Table 1:- Extent of Instructional Managers' (IMs) Implementation of the ALS Program in terms of Methods of Teaching.

\begin{tabular}{|c|c|c|c|}
\hline Methods of Teaching are ... & Mean & SD & $\begin{array}{l}\text { Descriptive } \\
\text { Interpretation }\end{array}$ \\
\hline 1. computer-based Instruction & 2.80 & 0.63 & To a moderate extent \\
\hline $\begin{array}{l}\text { 2. semi-structured group sessions with tutorial } \\
\text { sessions focus on specific content areas, topics } \\
\text { and issues }\end{array}$ & 3.40 & 0.52 & To a moderate extent \\
\hline $\begin{array}{l}\text { 3. unstructured discussions planned in advance } \\
\text { with exchange of ideas and sharing of experiences }\end{array}$ & 3.50 & 0.53 & To a high extent \\
\hline 4. TV - based teaching methods & 2.70 & 0.67 & To a moderate extent \\
\hline $\begin{array}{l}\text { 5. one-on-one/face to face session with individual } \\
\text { Tutorials }\end{array}$ & 3.60 & 0.52 & To a high extent \\
\hline $\begin{array}{l}\text { 6. utilizing resource persons for additional } \\
\text { knowledge, skills and inspirations }\end{array}$ & 3.30 & 0.67 & Implemented \\
\hline $\begin{array}{l}\text { 7. using role play method that encourages learners } \\
\text { to apply and practice newly acquired knowledge } \\
\text { and skills in realistic situations }\end{array}$ & 3.80 & 0.42 & To a high extent \\
\hline $\begin{array}{l}\text { 8. using demonstration sessions that develop } \\
\text { difficult competencies particularly in the problem- } \\
\text { solving and critical learning strand }\end{array}$ & 3.90 & 0.32 & To a high extent \\
\hline $\begin{array}{l}\text { 9. using workbooks/Textbooks for organizing } \\
\text { lessons and teaching materials for ALS }\end{array}$ & 3.50 & 0.71 & To a high extent \\
\hline $\begin{array}{l}\text { 10. scheduling remediation to support learners } \\
\text { experiencing difficulties in accomplishing the } \\
\text { competencies and skills identified in their } \\
\text { Individual Learning Agreement }\end{array}$ & 3.70 & 0.48 & To a high extent \\
\hline OVERALL & 3.42 & 0.290 & To a moderate Extent \\
\hline
\end{tabular}

Table 1 shows the extent of the instructional Managers' implementation of the ALS Program in the City School Division of Cabuyao in terms of methods of teaching. It can be observed from the table that in general, ALS respondents agree that the instructional managers' implementation the ALS teaching methods is to a moderate extent as shown by the composite mean of 3.42

Ebora and Guillo[6]cited that in ALS program, different teaching strategies can be used because students have different learning styles which can be learned from different approaches. Learners also came from the formal education and did not finish their studies because of economic and support issues. Therefore, the instructional managers can also consider using these teaching methodologies because other students may learn more from these. 
Table 2:- Extent of the Instructional Managers' (IMs) Implementation of the ALS Program in Terms of Instructional Materials, Facilities and Equipment.

\begin{tabular}{|l|r|r|r|}
\hline \multicolumn{1}{|c|}{ Instructional Materials, Facilities and Equipment } & Mean & SD & $\begin{array}{r}\text { Descriptive } \\
\text { Interpretation }\end{array}$ \\
\hline $\begin{array}{l}\text { 1. There are adequate visual and audio- } \\
\text { visual aids like poster, flipchart and video } \\
\text { used in teaching the lesson. }\end{array}$ & 3.50 & 0.53 & To a high extent \\
\hline $\begin{array}{l}\text { 2. Availability of updated ALS practice test } \\
\text { and reviewer. }\end{array}$ & 3.30 & 0.48 & To a moderate extent \\
\hline $\begin{array}{l}\text { 3. There are adequate teaching materials } \\
\text { like writing board, pen and eraser. }\end{array}$ & 3.60 & 0.52 & To a high extent \\
\hline $\begin{array}{l}\text { 4. The classroom is big enough to } \\
\text { accommodate the students. }\end{array}$ & 3.10 & 0.74 & To a moderate extent \\
\hline $\begin{array}{l}\text { 5. There is a projector for teaching which } \\
\text { helps encourage the learners to attend } \\
\text { their classes. }\end{array}$ & 3.30 & 0.64 & To a moderate extent \\
\hline $\begin{array}{l}\text { 6. The instructional materials are localized } \\
\text { and contextualized. }\end{array}$ & 3.90 & 0.32 & To a high extent \\
\hline $\begin{array}{l}\text { 7. There are available computers for } \\
\text { instruction. }\end{array}$ & 3.10 & 0.88 & To a moderate extent \\
\hline $\begin{array}{l}\text { 8. The learning areas are well lighted and } \\
\text { ventilated. }\end{array}$ & 3.70 & 0.48 & To a high extent \\
\hline 9. Comfort rooms are provided to learners. & 3.50 & 0.71 & To a high extent \\
\hline $\begin{array}{l}\text { 10. There are tables and chairs for writing, } \\
\text { reading and conducting various learning } \\
\text { activities. }\end{array}$ & & 0.32 & To a high extent \\
\hline & 3.49 & 0.197 & To a moderate extent \\
\hline
\end{tabular}

Table 2 illustrates that instructional managers, in general, have implemented the prescribed ALS instructional materials and facilities to a moderate extent as suggested by the computed overall weighted mean of 3.49 .

Fernandez,[7]explained that although, some ALS centers have available learning materials and learning facilities, yet, learners think that bigger classroom and computer-aided instruction are still needed and will inspire them to finish their learning modules. Good classroom condition, computers, projectors and others are materials that are also used in formal education which enhance students' motivation to learn. These can also be used while working at their integrated, self-instructional, self-paced and indigenized learning materials. With this, acquisition of skills to be globally competitive would be possible.

Table 3:- Extent of the Instructional Managers' (IMs) Implementation of the ALS Program in Terms of Community Support.

\begin{tabular}{|l|r|r|l|}
\hline \multicolumn{1}{|c|}{ Community support } & Mean & SD & $\begin{array}{r}\text { Descriptive } \\
\text { Interpretation }\end{array}$ \\
\hline 1. National Government/DepEd & 3.80 & 0.42 & To a high extent \\
\hline 2. Local Government Unit (LGU) & 3.90 & 0.32 & To a moderate extent \\
\hline 3. Civic Organizations & 2.90 & 0.99 & To a moderate extent \\
\hline $\begin{array}{l}\text { 4. Private Sectors: } \\
\text { Corporations/Companies }\end{array}$ & 2.80 & 0.42 & To a moderate extent \\
\hline 5. Private Citizens/Individuals & 2.60 & 0.82 & To a moderate extent \\
\hline $\begin{array}{l}\text { 6. Non-Government Organizations } \\
\text { (NGO's) }\end{array}$ & 2.80 & 1.03 & To a moderate extent \\
\hline 7. Church or Religious Sectors & 2.70 & 0.48 & To a moderate extent \\
\hline 8. Alumni/ALS Graduates & 2.80 & 0.92 & To a moderate extent \\
\hline 9. Private Schools & 2.60 & 0.52 & To a moderate extent \\
\hline 10. Elected Barangay Officials & 3.80 & 0.42 & To a high extent \\
\hline & 3.070 & 0.395 & To a moderate extent \\
\hline
\end{tabular}


Table 3 points out the extent of instructional managers' implementation of the ALS Program in terms of community support. It is illustrated that the respondents agreed that community support is implemented to a moderate extent as observed from the computed overall mean of 3.07.

Formento[8] explained that community support is felt by the learners and the instructional managers because the Sangguniang Barangay provided the learning centers while LGU provided materials and equipment needed by the learners. They are also concerned with the studies of their constituents so that no one among them would be left behind in terms of literacy.

Apaoet. al. [9] said that when the support of these sectors are fully obtained, it can help in building a learning center that is more capable of developing students' skills which would enable them to be more employable. Partnership with them may pave the way to better learning, better exposure and an effective means in cultivating the life skills. Maximizing the participation of stakeholders to bring the out-of-school youths and out-of-school adults to school and let them finish their studies thereby increase literacy. The strong support and collaboration of the stakeholders, the commitment of both the student learners and instructional managers are necessary in the effective implementation of the program.

Table 4:- Level of Instructional Managers' (IMs) Competence in the Implementation of ALS Program.

\begin{tabular}{|l|r|r|r|}
\hline \multicolumn{1}{|c|}{ Instructional Managers' Competence } & Mean & SD & $\begin{array}{r}\text { Descriptive } \\
\text { Interpretation }\end{array}$ \\
\hline $\begin{array}{l}\text { 1. formulate/adopt objectives of session guide in } \\
\text { ALS curriculum framework }\end{array}$ & 3.90 & 0.32 & Highly competent \\
\hline $\begin{array}{l}\text { 2. prepare and support instructional materials } \\
\text { teaching devices }\end{array}$ & 3.90 & 0.32 & Highly competent \\
\hline $\begin{array}{l}\text { 3. prepare prototype instructional materials for } \\
\text { literacy session utilization }\end{array}$ & 3.70 & 0.48 & Highly competent \\
\hline $\begin{array}{l}\text { 4. note observations on the various aspects of the } \\
\text { Programs }\end{array}$ & 3.70 & 0.48 & Highly competent \\
\hline $\begin{array}{l}\text { 5. provide appropriate mentoring to improve } \\
\text { performance of the learners }\end{array}$ & 3.60 & 0.52 & Highly competent \\
\hline $\begin{array}{l}\text { 6. document successful and effective strategies } \\
\text { used in the conduct of learning session in the } \\
\text { area. }\end{array}$ & 3.90 & 0.32 & Highly competent \\
\hline $\begin{array}{l}\text { 7. document success stories among learners and } \\
\text { significant changes observed in the community }\end{array}$ & 3.60 & 0.52 & Highly competent \\
\hline $\begin{array}{l}\text { 8. conduct pre- and post-assessment of the } \\
\text { Learners }\end{array}$ & 3.80 & 0.42 & Highly competent \\
\hline 9. prepare inventory of learners' competencies & & 0.52 & Highly competent \\
\hline $\begin{array}{l}\text { 10. coordinate with various agencies for skills } \\
\text { development to enhance and ensure the } \\
\text { learners' employability, efficiency, productivity, } \\
\text { and competitiveness in the labor market. }\end{array}$ & 3.730 & 0.241 & Highly competent \\
\hline
\end{tabular}

Table 4 shows the competency of instructional managers of the ALS Program in the City School Division of Cabuyao which pointed out that IMs competencies are observable and that they are highly competent as suggested by the computed overall mean of 3.73 .

Pilar[10]mentioned that instructional managers' competencies are very significant in ALS program because students learn more when the teachers are proficient and show mastery of the subject. Teachers should be competent and manifest their thorough knowledge in subject matter, in formulation of the questions to clarify a lesson/topic, usability of various aids to make the subject matter in the module more interesting, exploration of a variety of teaching strategies in the class, and providing inspiring tasks applicable to the real life scenarios. 
Indicator 10 is less observed from the instructional managers. However, Fernandez, quoted that students enrolled in ALS program are hopeful that they can be employed after graduation from the program and passing the A and $\mathrm{E}$ examination. Therefore, they also would like to have connection with agencies for their skills development as part of their on-the-job training. This can be part of engaging students to varied learning activities to develop their necessary skills.

Table 5:- A and E Passers' Improvement in Terms of Life Skills on Communication.

\begin{tabular}{|l|r|r|r|}
\hline \multicolumn{1}{|c|}{ Communication Skills } & Mean & SD & Interpretation \\
\hline $\begin{array}{l}\text { 1. can read and understand newspapers } \\
\text { and other reading materials both in } \\
\text { English and in Filipino. }\end{array}$ & 3.50 & 0.23 & Always \\
\hline $\begin{array}{l}\text { 2. is able to understand ads and other } \\
\text { printed materials along the highway. }\end{array}$ & 3.31 & 0.30 & Often \\
\hline $\begin{array}{l}\text { 3. when watching television, can easily } \\
\text { understand the plot and conversation } \\
\text { and dialogue in English }\end{array}$ & 3.27 & 0.24 & Often \\
\hline $\begin{array}{l}\text { 4. can easily follow directions and } \\
\text { instructions which are expressed in }\end{array}$ & 3.31 & 0.22 & Often \\
\hline $\begin{array}{l}\text { English language } \\
\text { Language }\end{array}$ & 3.19 & 0.16 & Often \\
\hline OVERALL & 3.32 & 0.19 & Often \\
\hline
\end{tabular}

A and E passers often show improvement in terms of life skills on communication as presented in Table 5 and as revealed by its composite mean of 3.32 .

With this, Guerero[11] emphasized that the aim of ALS to develop competencies of knowledge, attitude, values and skills that equally promote the same goal which is functional literacy is achieved.

Kale[12]also noted that the development of an Alternative Learning System (ALS) has been a dream of the Philippine government for over twenty years. With the development of ALS, thousands of out-of-school youth and adults from the most impoverished sectors of Filipino society will expectedly have an alternative means to improve their basic education skills including speaking English language and competencies as a pathway to a better tomorrow.

Table 6:- A and E Passers' Improvement in Terms of Life Skills on Scientific and Critical Thinking.

\begin{tabular}{|c|c|c|c|}
\hline Scientific and Critical Thinking Skills & Mean & SD & $\begin{array}{r}\text { Descriptive } \\
\text { Interpretation }\end{array}$ \\
\hline $\begin{array}{l}\text { 6. can understand the environment and } \\
\text { the relationship of the things around } \\
\text { and their role in improving life }\end{array}$ & 3.36 & 0.27 & Often \\
\hline $\begin{array}{l}\text { 7. can investigate a societal issue before } \\
\text { making a judgment }\end{array}$ & 3.19 & 0.24 & Often \\
\hline $\begin{array}{l}\text { 8. can identify issues affecting family and } \\
\text { Society }\end{array}$ & 3.31 & 0.24 & Often \\
\hline $\begin{array}{l}\text { 9. can recognize that everything changes } \\
\text { and can compare life situation in the } \\
\text { past with the present in terms of } \\
\text { progress in science and technology }\end{array}$ & 3.22 & 0.28 & Often \\
\hline $\begin{array}{l}\text { 10. can apply scientific values and } \\
\text { demonstrate positive attitudes in } \\
\text { dealing with the advances of science } \\
\text { and technology in various life situations. }\end{array}$ & 3.20 & 0.33 & Often \\
\hline OVERALL & 3.26 & 0.24 & Often \\
\hline
\end{tabular}


Table 6 reveals that A and E passers display improvement in their life skills on scientific and critical thinking as proven by the overall mean of 3.26 .

It is a good idea that these scientific and critical thinking skills are always observable among the ALS learners so that they can analyze complex problems, which enable them to investigate questions with no clear-cut answers, evaluate different points of view of sources of information and draw appropriate conclusions based on evidence and reasoning.

Apao, et al. on the implementation of the Alternative Learning System said, the program enables to increase literacy as evident in the successful passers of the alternative Learning System Accreditation and Equivalency (ALS A\&E) Test.

Table 7:- A and E Passers' Improvement in Terms of Life Skills on Mathematics and Problem Solving.

\begin{tabular}{|l|r|r|r|}
\hline \multicolumn{1}{|c|}{ Mathematical Skills } & Mean & SD & $\begin{array}{r}\text { Descriptive } \\
\text { Interpretation }\end{array}$ \\
\hline $\begin{array}{l}\text { 11. can demonstrate the importance and value of } \\
\text { mathematics as a means of communicating } \\
\text { and solving problems in daily life, e.g., } \\
\text { computing and comparing costs of goods. }\end{array}$ & 3.34 & 0.29 & Often \\
\hline $\begin{array}{l}\text { 12. can demonstrate creativity, interest, and } \\
\text { curiosity in asking questions, defining } \\
\text { problems, considering different strategies, and } \\
\text { finding appropriate solutions to problems } \\
\text { through mathematics, e.g., analyzing the } \\
\text { given data in a problem and identifying what } \\
\text { mathematical operation will be applied to }\end{array}$ & 3.33 & 0.22 & \\
solve the problem. & & & \\
\hline $\begin{array}{l}\text { 13. can exhibit honesty and accuracy in collecting } \\
\text { and reporting mathematical data, e.g., use of } \\
\text { untampered measuring instruments such as } \\
\text { measuring tapes, weighing scales, volume }\end{array}$ & & & \\
measurers, and electric and water meters. & & & \\
\hline $\begin{array}{l}\text { 14. can integrate mathematics with disciplines such } \\
\text { as economics, agricultural studies, } \\
\text { communication arts, science and technology, } \\
\text { geography, cooking, architecture, music, e.g., } \\
\text { use of comprehension skills in analyzing } \\
\text { problems that would lead to the most accurate } \\
\text { way of solving the problem, interpret the } \\
\text { number of beats musical notes/rests in a } \\
\text { musical composition, etc. }\end{array}$ & & & \\
\hline $\begin{array}{l}\text { 15. can read and write the money value (in peso } \\
\text { and centavos) and compares values of different } \\
\text { denominations of Philippine coins and paper bills }\end{array}$ & & & \\
\hline \begin{tabular}{l} 
OVERALL \\
\hline
\end{tabular} & & & \\
\hline
\end{tabular}

Table 7 illustrates that $\mathrm{A}$ and $\mathrm{E}$ passers often demonstrate improvement in their life skills in Mathematics as revealed by its composite mean of 3.30 .

Ebora and Guillomentioned that one of the objectives of the ALS Program is for all learners to become functionally literate. When they can already read and write value of money and can compare money in different denominations, it indicates that they can engage in different activities in which literacy in money is required for effective functions like selling and buying activities and others. Although, such skill needs to be more exposed so that it will be more developed, it has somewhat a considerable positive effect not only on their personal development but also in economic and social terms which can be considered as a guarantee for one's success. 
Table 8:- A and E Passers; Improvement in Terms of Life Skills on Life and Career.

\begin{tabular}{|l|r|r|r|}
\hline \multicolumn{1}{|c|}{ Life and Career Skills } & Mean & SD & $\begin{array}{r}\text { Descriptive } \\
\text { Interpretation }\end{array}$ \\
\hline $\begin{array}{l}\text { 16. Assess one's personal strengths and } \\
\text { attributes as a potential employee }\end{array}$ & 3.31 & 0.22 & Often \\
\hline $\begin{array}{l}\text { 17. Appreciate the importance of planning for life } \\
\text { and career development }\end{array}$ & 3.42 & 0.24 & Often \\
\hline $\begin{array}{l}\text { 18. Demonstrate awareness and understanding of } \\
\text { the concept of career-related terms such as } \\
\text { career, occupation, job and work in planning } \\
\text { for the future }\end{array}$ & 3.43 & 0.24 & Often \\
\hline $\begin{array}{l}\text { 19. Demonstrate knowledge of how their } \\
\text { experiences and decisions have already } \\
\text { influenced their lives and will affect their lives } \\
\text { in the future }\end{array}$ & 3.32 & 0.23 & \\
\hline $\begin{array}{l}\text { 20. Demonstrate knowledge of themselves: their } \\
\text { relationships with others, their skills, their } \\
\text { educational plans, future dreams, their } \\
\text { predictions for the future to develop life and } \\
\text { career plans that include short- and long-term } \\
\text { goals }\end{array}$ & 3.40 & 0.22 & Often \\
\hline \begin{tabular}{l} 
OVERALL \\
\hline
\end{tabular} & & 3.37 & \\
\hline
\end{tabular}

Table 8 displays the A and E passers' improvement in terms of life skills on life and career. It can be seen that the respondents often demonstrate awareness and understanding of the concept of career-related terms such as career, occupation, job and work in planning for the future as proposed by the computed mean of 3.43.

The study of Tangonan[13]suggested that the ALS program can be considered successful in helping the learners grow personally. This means that this can also be true to others who will be enrolled in the ALS program. With this development, thousands of out-of-school youth and adults from the most impoverished sectors of Filipino society will expectedly have an alternative means to improve their basic education skills and competencies as a pathway to a better tomorrow.

Table 9:- A and E Passers' Improvement in Terms of Values Development on Understanding Self and Society.

\begin{tabular}{|l|r|r|r|}
\hline \multicolumn{1}{|c|}{ Understanding Self and Society } & Mean & SD & $\begin{array}{r}\text { Descriptive } \\
\text { Interpretation }\end{array}$ \\
\hline $\begin{array}{l}\text { 1. Describe oneself by determining own } \\
\text { hobby, interest, skills and talents }\end{array}$ & 3.48 & 0.27 & Often \\
\hline $\begin{array}{l}\text { 2. Evaluate one's worth in terms of } \\
\text { values/character through identifying } \\
\text { strengths and weakness }\end{array}$ & 3.34 & 0.31 & Often \\
\hline $\begin{array}{l}\text { 3. Observe and develop good values that are } \\
\text { learned from elders }\end{array}$ & 3.46 & 0.32 & Often \\
\hline 4. Become self-directed & 3.28 & 0.27 & \\
\hline 5. Develop self-discipline at all times & 3.36 & 0.26 & Often \\
\hline 6. Be able to manage emotions and impulses & 3.38 & 0.24 & Often \\
\hline $\begin{array}{l}\text { 7. Improve one's sense of Responsibility and } \\
\text { Accountability }\end{array}$ & 3.35 & 0.37 & Often \\
\hline $\begin{array}{l}\text { 8. Strengthen one's personal conviction by } \\
\text { taking a stand on social issues and decide } \\
\text { when to take a stand and when to } \\
\text { compromise }\end{array}$ & 3.24 & 0.34 & Often \\
\hline $\begin{array}{l}\text { 9. Plan for personal change to develop one's } \\
\text { Potential }\end{array}$ & & & Often \\
\hline \begin{tabular}{l} 
OVERALL \\
\hline
\end{tabular} & 3.26 & & 0.23 \\
\end{tabular}


Table 10 depicts that $\mathrm{A}$ and $\mathrm{E}$ passers often show improvement in all indicators under values development on understanding self and society with a composite of 3.36 .

This means that they now know the things that describe themselves. The way they see things has changed. When one learner was still an out-of-school youth, he felt inferior and deprived. But after graduation and passing the A and E test, he now feels that he belongs. Egcas and Garganera[14]quoted, ALS program was effective in nurturing the life skills and values development of the learners.

Atilano et.al.[15]mentioned that these values can be more developed as they get exposed to real life situations. At least, with the ALS program, they feel equality and sense of belongingness among their social groups. The program improved the quality of living of the respondent learner-passers as compared to how they lived before ALS engagement.

Table 10:- A and E Passers' Improvement in Terms of Values Development on Digital Citizenship.

\begin{tabular}{|l|r|r|r|}
\hline \multicolumn{1}{|c|}{ Digital Literacy } & Mean & SD & $\begin{array}{r}\text { Descriptive } \\
\text { Interpretation }\end{array}$ \\
\hline $\begin{array}{l}\text { 10. Demonstrate smooth interpersonal } \\
\text { relationships between and among family } \\
\text { members in the use technology }\end{array}$ & 3.42 & 0.27 & Often \\
\hline $\begin{array}{l}\text { 11. Build harmonious relationships with } \\
\text { others by observing the Golden Rule } \\
\text { using multi-media, }\end{array}$ & 3.40 & 0.12 & Often \\
\hline $\begin{array}{l}\text { 12. Develop a sense of responsibility and } \\
\text { accountability on the use of technology }\end{array}$ & 3.48 & 0.26 & Often \\
\hline $\begin{array}{l}\text { 13. Take pride in being a Filipino, its } \\
\text { traditions, culture and beliefs }\end{array}$ & 3.59 & 0.25 & Always \\
\hline $\begin{array}{l}\text { 14. Respect others and recognize one's } \\
\text { rights, skills, talents, and abilities in the } \\
\text { use of all media }\end{array}$ & 3.51 & 0.34 & Always \\
\hline $\begin{array}{l}\text { 15. Recognize and respect the use of internet } \\
\text { Meaningfully }\end{array}$ & 3.46 & 0.19 & Often \\
\hline OVERALL & & 0.19 & \\
\hline
\end{tabular}

A and E passers' improvement in terms of values development on digital citizenship is revealed in Table 10. It is noted that the learners always respect others and recognize one's rights, skills, talents, and abilities in the use of all media and they also always recognize and respect the use of internet meaningfully as indicated by the computed mean of 3.59 and 3.51 , respectively.

Apao, et al. said that it is very essential that ALS learners are updated of the present media technology and also able to demonstrate digital and media literacy competence. This will be of great help if they choose to pursue higher education or engage in a job which requires digital literacy.

Meanwhile, with regard to the other indicators, Tangonan mentioned that the learners have probably developed the know-how of digital literacy but must develop the responsible use which is more important. Values on respect of other's feeling and rights are very essential on the use of multimedia, especially the social media. The objectives of ALS are similar to those of formal education-acquisition of knowledge, development of skills and formation of desirable Filipino values and attitudes. The objectives are as diverse as the needs of individuals but the goal is the development of self-reliant, self-sufficient, and self-disciplined citizens.

Table 11:- A and E Non-Passers' Improvement in Terms of Life Skills on Communication.

\begin{tabular}{|l|r|r|r|}
\hline Communication Skills & Mean & SD & $\begin{array}{r}\text { Descriptive } \\
\text { Interpretation }\end{array}$ \\
\hline $\begin{array}{l}\text { 1. can read and understand newspapers } \\
\text { and other reading materials both in } \\
\text { English and in Filipino. }\end{array}$ & 3.47 & 0.25 & Often \\
\hline
\end{tabular}




\begin{tabular}{|l|r|r|r|}
\hline $\begin{array}{l}\text { 2. is able to understand ads and other } \\
\text { printed materials along the highway. }\end{array}$ & 3.34 & 0.33 & Often \\
\hline $\begin{array}{l}\text { 3. when watching television, can easily } \\
\text { understand the plot and conversation } \\
\text { and dialogue in English }\end{array}$ & 3.33 & 0.15 & Often \\
\hline $\begin{array}{l}\text { 4. can easily follow directions and } \\
\text { instructions which are expressed in } \\
\text { English language }\end{array}$ & 3.41 & 0.19 & Often \\
\hline $\begin{array}{l}\text { 5. can converse using simple English } \\
\text { Language }\end{array}$ & 3.22 & 0.24 & Often \\
\hline OVERALL & 3.35 & 0.20 & Often \\
\hline
\end{tabular}

Meanwhile, Table 11 explains that $\mathrm{A}$ and $\mathrm{E}$ non-passers also often demonstrate improvement in their life skills on communication as indicated by its composite mean of 3.35 .

Based on the responses, their improvement is almost not different with the A and E passers. However, Guerero said that there may be other reasons but it can be said that learning the basic skills of communication is not enough. With the operationalization of ALS by the DepEd, these learners now have other options for learning.

Villenes[16]mentioned that lack of commitment, motivation and maturity, less effort, lack of self-confidence and fear of examination are the prime factors of failing an examination. Some said that examination anxiety, inappropriate study habits and inadequate preparation make a student fail. These may be the reason that caused the failure.

Table 12:- A and E Non-Passers' Improvement in Terms of Life Skills on Scientific and Critical Thinking.

\begin{tabular}{|c|c|c|c|}
\hline Scientific and Critical Thinking Skills & Mean & SD & $\begin{array}{r}\text { Descriptive } \\
\text { Interpretation }\end{array}$ \\
\hline $\begin{array}{l}\text { 6. can understand the environment and the } \\
\text { relationship of the things around and their } \\
\text { role in improving life }\end{array}$ & 3.46 & 0.20 & Often \\
\hline $\begin{array}{l}\text { 7. can investigate a societal issue before } \\
\text { making a judgment }\end{array}$ & 3.25 & 0.26 & Often \\
\hline $\begin{array}{l}\text { 8. can identify issues affecting family and } \\
\text { Society }\end{array}$ & 3.37 & 0.24 & Often \\
\hline $\begin{array}{l}\text { 9. can recognize that everything changes and } \\
\text { can compare life situation in the past with } \\
\text { the present in terms of progress in science } \\
\text { and technology }\end{array}$ & 3.31 & 0.20 & Often \\
\hline $\begin{array}{l}\text { 10. can apply scientific values and } \\
\text { demonstrate positive attitudes in dealing } \\
\text { with the advances of science and } \\
\text { technology in various life situations. }\end{array}$ & 3.38 & 0.20 & Often \\
\hline OVERALL & 3.35 & 0.18 & Often \\
\hline
\end{tabular}

A and E non-passers' improvement in terms of life skills on scientific and critical thinking is presented in Table 12. It is revealed that non- passers often exhibit improvement on this aspect as indicated by its composite mean of 3.35. It is interesting to note that non-passers have rated the same improvement greater than the passers. With this, Lua[17]statedthat the learners with the help of the teachers should also be well guided in the learning centers and provide more assistance which includes intervention programs and encourage them to devise their own initiatives to guarantee learning enough to ensure that those who finish elementary and secondary levels complete basic education with satisfactory achievement level.

Table 13:- A and E Non-Passers' Improvement in Terms of Life Skills on Mathematics and Problem Solving.

\begin{tabular}{|r|r|r|r|}
\hline Mathematical Skills & Mean & SD & $\begin{array}{r}\text { Descriptive } \\
\text { Interpretation }\end{array}$ \\
\hline
\end{tabular}




\begin{tabular}{|l|c|c|c|}
\hline $\begin{array}{l}\text { 11. can demonstrate the importance and value of mathematics as a means of } \\
\text { communicating and solving problems in daily life, e.g., computing and } \\
\text { comparing costs of goods }\end{array}$ & 3.56 & 0.22 & Always \\
\hline $\begin{array}{l}\text { 12. can demonstrate creativity, interest, and curiosity in asking questions, } \\
\text { defining problems, considering different strategies, and finding appropriate } \\
\text { solutions to problems through mathematics, e.g., analyzing the given data in a } \\
\text { problem and identifying what mathematical operation will be applied to solve } \\
\text { the problem. }\end{array}$ & 3.47 & 0.22 & Often \\
\hline $\begin{array}{l}\text { 13. can exhibit honesty and accuracy in collecting and reporting mathematical } \\
\text { data, e.g., use of untampered measuring instruments such as measuring tapes, } \\
\text { weighing scales, volume measurers, and electric and water meters. }\end{array}$ & 3.41 & 0.24 & Often \\
\hline $\begin{array}{l}\text { 14. can integrate mathematics with disciplines such as economics, agricultural } \\
\text { studies, communication arts, science and technology, geography, cooking, } \\
\text { architecture, music, e.g., use of comprehension skills in analyzing problems } \\
\text { that would lead to the most accurate way of solving the problem, interpret the } \\
\text { number of beats musical notes/rests in a musical composition, etc. }\end{array}$ & 3.32 & 0.19 & Often \\
\hline $\begin{array}{l}\text { 15. can read and write the money value (in peso and centavos) and compares } \\
\text { values of different denominations of Philippine coins and paper bills }\end{array}$ & 3.50 & 0.23 & Always \\
\hline OVERALL & 3.45 & 0.20 & \\
\hline
\end{tabular}

Table 13 states that in indicators 11 and 15, A and E non-passers always show improvement in their life skills on Mathematics with computed means of 3.56 and 3.50, respectively.

Surprisingly, non-passers rated their improvement higher than that of the A and E passers' progress in Mathematics. Villenessaid these non-passers belong to the 50 to 60 percent failures in the A and E test. Although, Atilano et.al. claimed that ALS program was effective in nurturing the life skills and values development of the learners, yet, not all those who attempted to take the equivalency test were successful. With these, it is recommended that students' performance and development should be monitored so that they will be ready to the ALS equivalency test. Therefore, Villenes cited that they need to be provided with quality education beyond classroom.

Table 14:- A and E Non-Passers' Improvement in Terms of Life Skills on Life and Career.

\begin{tabular}{|c|c|c|c|}
\hline Life and Career Skills & Mean & SD & $\begin{array}{l}\text { Descriptive } \\
\text { Interpretation }\end{array}$ \\
\hline $\begin{array}{l}\text { 16. Assess one's personal strengths and } \\
\text { attributes as a potential employee }\end{array}$ & 3.14 & 0.26 & Often \\
\hline $\begin{array}{l}\text { 17. Appreciate the importance of planning } \\
\text { for life and career development }\end{array}$ & 3.53 & 0.26 & Always \\
\hline $\begin{array}{l}\text { 18. Demonstrate awareness and } \\
\text { understanding of the concept of } \\
\text { career-related terms such as career, } \\
\text { occupation, job and work in planning } \\
\text { for the future }\end{array}$ & 3.53 & 0.22 & Always \\
\hline $\begin{array}{l}\text { 19. Demonstrate knowledge of how their } \\
\text { experiences and decisions have } \\
\text { already influenced their lives and will } \\
\text { affect their lives in the future }\end{array}$ & 3.51 & 0.22 & Always \\
\hline $\begin{array}{l}\text { 20. Demonstrate knowledge of } \\
\text { themselves: their relationships with } \\
\text { others, their skills, their educational } \\
\text { plans, future dreams, their predictions } \\
\text { for the future to develop life and } \\
\text { career plans that include short- and } \\
\text { long-term goals }\end{array}$ & 3.48 & 0.22 & Often \\
\hline OVERALL & 3.44 & 0.19 & Often \\
\hline
\end{tabular}


Furthermore, Table 14 shows the A and E non-passers often show improvement on their life and career skills as indicated by the composite mean of 3.44. However, indicators 17, 18, and 19 posit a verbal interpretation of 'always' as suggested by the computed mean of 3.53 and 3.51 , respectively.

Like the A and E passers, non-passers have also rated this higher because according to them they were able to acquire these skills. Lua mentioned that planning, especially about career-related terms such as career, occupation, job and work in planning for the future is very essential because this can be a strong weapon to combat poverty and uplift their status of living. Thus, everyone enthusiastically tries to acquire education by all means.

Table 15:- A and E Non-Passers' Improvement in Terms of Values Development on Understanding Self and Society.

\begin{tabular}{|l|l|l|l|}
\hline $\begin{array}{l}\text { Understanding Self and Society } \\
\begin{array}{l}\text { 1. Describe oneself by determining own } \\
\text { hobby, interest, skills and talents }\end{array}\end{array}$ & Mean & $\begin{array}{l}\text { Descriptive } \\
\text { Interpretation }\end{array}$ \\
\hline $\begin{array}{l}\text { 2. Evaluate one's worth in terms of } \\
\text { values/character through identifying } \\
\text { strengths and weakness }\end{array}$ & 3.33 & Always \\
\hline $\begin{array}{l}\text { 3. Observe and develop good values that } \\
\text { are learned from elders }\end{array}$ & 3.49 & 0.23 & Often \\
\hline $\begin{array}{l}\text { 4. Become self-directed } \\
\text { 5. Develop self-discipline at all times }\end{array}$ & 3.38 & 0.28 & Often \\
\hline $\begin{array}{l}\text { 6. Be able to manage emotions and } \\
\text { Impulses }\end{array}$ & 3.38 & 0.23 & Often \\
\hline $\begin{array}{l}\text { 7. Improve one's sense of Responsibility } \\
\text { and Accountability }\end{array}$ & 3.34 & 0.19 & Often \\
\hline $\begin{array}{l}\text { 8. Strengthen one's personal conviction } \\
\text { by taking a stand on social issues and } \\
\text { decide when to take a stand and when } \\
\text { to compromise }\end{array}$ & 3.40 & 0.22 & Often \\
\hline $\begin{array}{l}\text { 9. Plan for personal change to develop } \\
\text { one's potential }\end{array}$ & 3.38 & 0.21 & Often \\
\hline \begin{tabular}{l} 
OVERALL \\
\hline
\end{tabular} & 3.39 & 0.22 & Often \\
\hline
\end{tabular}

The A and E non-passers' improvement in their values development on understanding self and society is presented in Table 15. It can be seen that non-passers said and gave higher rating to the idea that they always describe oneself by determining own hobby, interest, skills and talents as indicated by the mean of 3.57 .

Although, they did not pass the A and E test yet, they learn to understand themselves. They can have a clear description about their personality and talents. Like those who passed, Atilano et.al. cited that the ALS program enables them to improve their quality of living which is one of the vital concerns that should be addressed.

Table 16:- A and E Non-Passers' Improvement in Terms of Values Development on Digital Citizenship.

\begin{tabular}{|l|r|r|r|}
\hline \multicolumn{1}{|c|}{ Digital Citizenship } & Mean & SD & $\begin{array}{r}\text { Descriptive } \\
\text { Interpretation }\end{array}$ \\
\hline $\begin{array}{l}\text { 10. Demonstrate smooth interpersonal } \\
\text { relationships between and among } \\
\text { family members in the use technology }\end{array}$ & 3.37 & 0.29 & Often \\
\hline $\begin{array}{l}\text { 11. Build harmonious relationships with } \\
\text { others by observing the Golden Rule } \\
\text { using multi-media, }\end{array}$ & 3.48 & 0.26 & Often \\
\hline $\begin{array}{l}\text { 12. Develop a sense of responsibility and } \\
\text { accountability on the use of technology }\end{array}$ & 3.32 & 0.25 & Often \\
\hline $\begin{array}{l}\text { 13. Take pride in being a Filipino, its } \\
\text { traditions, culture and beliefs }\end{array}$ & 3.36 & 0.25 & Often \\
\hline
\end{tabular}




\begin{tabular}{|l|r|r|r|}
\hline $\begin{array}{l}\text { 14. Respect others and recognize one's } \\
\text { rights, skills, talents, and abilities in } \\
\text { the use of all media }\end{array}$ & 3.55 & 0.20 & Always \\
\hline $\begin{array}{l}\text { 15. Recognize and respect the use of } \\
\text { internet meaningfully }\end{array}$ & 3.50 & 0.22 & Always \\
\hline OVERALL & 3.43 & 0.22 & Often \\
\hline
\end{tabular}

Table 16 displays the A and $\mathrm{E}$ non-passers improvement in terms of values development on digital citizenship. The table explains that just like the A and E passers, non-passers also always develop improvement on indicators14 and 15 as proven by the computed means of 3.55 and 3.50 , respectively.

They, too, were able to acquire skills related to digital citizenship. Apao, et al. stated, now that the world is in the 21 st century and almost everything has something to do with modern technology, it is essential that everyone has these skills so they can effectively participate in the present society. Although, this group did not make it up in the equivalency test, yet, the ALS program was able to effectively cultivate students' life skills and has improved the quality of living of the respondents as they continue their pursuit for meaning and significance in life.

Table 17:- Significant Relationship Between the Extent of ALS Program Implementation and ALS Passers' Improvement in Terms of Life Skills.

\begin{tabular}{|c|c|c|c|}
\hline Extent of ALS Implementation & $\begin{array}{llr}\text { ALS } & \text { Passer } & \begin{array}{r}\text { Learners } \\
\text { Improvement }\end{array}\end{array}$ & $\begin{array}{l}\text { Correlation } \\
\text { Coefficient }\end{array}$ & $\begin{array}{r}\mathrm{P}- \\
\text { value }\end{array}$ \\
\hline \multirow[t]{4}{*}{ Methods of teaching } & Communication Skills & 0.457 & 0.182 \\
\hline & Scientific and Critical Thinking & 0.512 & 0.130 \\
\hline & Mathematical Skills & 0.467 & 0.174 \\
\hline & Life and Career Skills & 0.759 & $0.011 *$ \\
\hline \multirow{4}{*}{$\begin{array}{llr}\text { Instructional } & \text { Materials, } & \text { Facilities and } \\
\text { Equipment }\end{array}$} & Communication Skills & 0.041 & 0.910 \\
\hline & Scientific and Critical Thinking & 0.092 & 0.800 \\
\hline & Mathematical Skills & 0.106 & 0.771 \\
\hline & Life and Career Skills & 0.065 & 0.858 \\
\hline \multirow[t]{4}{*}{ Community Support } & Communication Skills & 0.676 & $0.032 *$ \\
\hline & Scientific and Critical Thinking & 0.430 & 0.214 \\
\hline & Mathematical Skills & 0.568 & 0.087 \\
\hline & Life and Career Skills & 0.146 & 0.688 \\
\hline \multirow[t]{4}{*}{ Instructional Managers' Competence } & Communication Skills & 0.046 & 0.900 \\
\hline & Scientific and Critical Thinking & 0.108 & 0.766 \\
\hline & Mathematical Skills & 0.059 & 0.812 \\
\hline & Life and Career Skills & 0.203 & 0.574 \\
\hline
\end{tabular}

Table 17 reveals the test of significant relationship between the extent of ALS Program implementation and ALS Passers' improvement in terms of life skills. It is presented in the table that ALS passers' improvement in life and career skills is highly correlated to the methods of teaching of the instructional managers as suggested by the computed correlation coefficient of 0.759 while the p-value of 0.011 which is less than the 0.05 level of significance indicates a high relationship between the two variables. This implies that the methods of teaching affect how the students learn the life and career skills. The students tend to remember skills which used practical examples. Since, the concept of career-related terms such as career, occupation, job and work in planning for the future can be taught through the use of demonstration session, many of the students learn from this.

Although, Mercado [18] said the said program is an alternative to the regular classroom, yet, the IMs were able to provide a caring atmosphere in which students learn the skills necessary to redirect their lives. In addition, the findings reveal that the community support and the communication skills of the ALS passers have moderate correlation as shown by the computed correlation coefficient of 0.676 . The p-value of 0.032 which is less than the 
0.05 level of significance indicates a significant relationship between the two variables. It denotes that frequent support of the LGU tends to encourage them, thus, improvement in reading and understanding newspapers and other reading materials both in English and in Filipino is achieved. They may be inspired by these officials' continual visits or their frequent encounter with them enables them to practice their communication skills. The strong support and collaboration of the stakeholders, the commitment of both the learners and mobile teachers are necessary in the effective implementation and success of the program (Apao, et al., 2014).

On the other hand, instructional materials, facilities and equipment and instructional managers' competence are not in any way related to ALS passers improvement in communication skills, scientific and critical thinking skills, mathematic skills and life and career skills.

Table 18:- Significant Relationship Between the Extent of ALS Program Implementation and ALS Passers' Improvement in Terms of Values Development.

\begin{tabular}{|r|r|r|r|}
\hline Extent of ALS Implementation & ALS Passer Learners Improvement & $\begin{array}{r}\text { Correlation } \\
\text { Coefficient }\end{array}$ & P-value \\
\hline Methods of teaching & Understanding Self and Society & 0.528 & 0.116 \\
\cline { 2 - 4 } & Digital Citizenship & 0.542 & 0.108 \\
\hline Instructional Materials, Facilities and & & & \\
\cline { 2 - 4 } & & 0.036 & 0.922 \\
\hline Equipment & Understanding Self and Society & 0.961 \\
& Digital Citizenship & 0.018 & 0.408 \\
\hline Community Support & Understanding Self and Society & -0.295 & 0.513 \\
\cline { 2 - 4 } & Digital Citizenship & -0.235 & 0.374 \\
\hline Instructional Managers' Competence & Understanding Self and Society & 0.316 & 0.591 \\
\cline { 2 - 4 } & Digital Citizenship & 0.194 & \\
\cline { 2 - 4 } & & &
\end{tabular}

Table 18 shows the test of significant relationship between the extent of ALS Program implementation and ALS passers' improvement in terms of values development. It can be inferred from the table that there is no significant relationship between the extent of ALS implementation in terms of methods of teaching, instructional materials and equipment, community support and instructional managers' competence and the ALS passers' improvement in their values development in terms of understanding themselves and digital citizenship. The result is the same with the study conducted by Fernandez (2013) on the teachers' competence and learners' performance in the Alternative Learning System where there is no significant relationship between the teachers ${ }^{\text {ee }}$ competence and learners ${ }^{\text {ee }}$ performance.

It means that passers have learned and have developed a clear understanding of themselves and have established the respect and responsible use of technology with their eagerness and own motivation to learn. It is because of their own initiative that these students really did their best because they believe that education is one of the important needs of an individual to guarantee for one's success (Ebora and Guillo, 2018). On the same manner, the Filipino families recognize the importance of acquiring education towards a productive living.

Table 19:- Significant Relationship Between the Extent of ALS Program Implementation and ALS Non-Passers' Improvement in Terms of Life Skills.

\begin{tabular}{|l|l|l|l|}
\hline Extent of ALS Implementation & $\begin{array}{l}\text { ALS Passer Learners } \\
\text { Improvement }\end{array}$ & $\begin{array}{l}\text { Correlation } \\
\text { Coefficient }\end{array}$ & $\begin{array}{l}\text { P- } \\
\text { value }\end{array}$ \\
\hline \multirow{2}{*}{ Methods of teaching } & & -0.061 & 0.866 \\
\cline { 3 - 4 } & Communication Skills & 0.150 & 0.170 \\
\cline { 3 - 5 } & Scientific and Critical Thinking & 0.471 & 0.144 \\
\cline { 3 - 5 } & Mathematical Skills & 0.497 & 0.921 \\
\cline { 3 - 5 } & Life and Career Skills & -0.036 & 0.718 \\
\hline
\end{tabular}




\begin{tabular}{|l|l|l|l|}
\hline \multirow{4}{*}{ Community Support } & Mathematical Skills & 0.067 & 0.854 \\
\cline { 2 - 4 } & Life and Career Skills & 0.284 & 0.426 \\
& & & \\
\cline { 2 - 4 } & Communication Skills & -0.307 & 0.389 \\
\cline { 2 - 4 } & Scientific and Critical Thinking & -0.529 & 0.116 \\
\cline { 2 - 4 } & Mathematical Skills & -0.522 & 0.122 \\
\cline { 2 - 4 } & Life and Career Skills & -0.271 & 0.450 \\
\hline Instructional Managers' Competence & & & \\
\cline { 2 - 4 } & Communication Skills & -0.608 & 0.062 \\
\cline { 2 - 4 } & Scientific and Critical Thinking & -0.440 & 0.203 \\
\cline { 2 - 3 } & Mathematical Skills & -0.177 & 0.624 \\
\cline { 2 - 4 } & Life and Career Skills & -0.008 & 0.983 \\
\hline
\end{tabular}

Table 19 presents the test of significant relationship between the extent of ALS Program implementation and ALS non-passers' improvement in terms of life skills. It is depicted in the table that there is no significant relationship between the extent of ALS implementation in terms of methods of teaching, instructional materials and equipment, community support and instructional managers' competence and to the ALS non-passers' improvement in their communication skills, scientific and critical thinking skills, mathematical skills and life and career skills.

Non-passers' improvement in their life skills is not related to the ALS Program implementation. The result is contrary to the study of Ebora and Guillo (2018) where ALS instruction considering program offerings, and learning facilities and materials have significant relationship to the performance of the ALS graduates. The adequacy of the materials and facilities contributed to their success.

In this study, the learners who worked independently focused mainly on their learning materials that are designed as self-instructional and learn at their own pace and study at their own time. They never thought that they could ask questions and clarify things through their teachers. They thought that they would be able to understand everything by themselves and so, the ALS procedures in the learning centers have not contributed significantly to the improvement in their life skills. May be they did not anticipate the difficulty of the examination and just rely on their own.

Table 20:- Significant Relationship Between the Extent of ALS Program Implementation and ALS NonPassers' Improvement in Terms of Values Development.

\begin{tabular}{|l|l|l|l|}
\hline Extent of ALS Implementation & ALS Non-Passer Learners Improvement & $\begin{array}{l}\text { Correlation } \\
\text { Coefficient }\end{array}$ & P-value \\
\hline \multirow{2}{*}{ Methods of teaching } & & 0.424 & 0.222 \\
\hline & Understanding Self and Society & 0.356 & 0.313 \\
\cline { 2 - 4 } & Digital Citizenship & & \\
\hline $\begin{array}{l}\text { Instructional Materials, Facilities } \\
\text { and Equipment }\end{array}$ & Understanding Self and Society & 0.023 & 0.949 \\
\cline { 2 - 4 } & Digital Citizenship & -0.047 & 0.847 \\
\hline Community Support & Understanding Self and Society & -0.201 & 0.577 \\
\cline { 2 - 4 } & Digital Citizenship & -0.581 & 0.078 \\
\hline $\begin{array}{l}\text { Instructional } \\
\text { Competence }\end{array}$ & Understanding Self and Society & -0.200 & 0.580 \\
\cline { 2 - 4 } & Digital Citizenship & -0.181 & 0.616 \\
\hline
\end{tabular}

The test of significant relationship between the extent of ALS program implementation and non-passers' improvement in terms of values development is illustrated in Table 20. It is noted in the table that there is no significant relationship existed between methods of teaching, instructional facilities and equipment, community support, and instructional managers' competencies and non-passers values development in understanding self and society and digital citizenship as indicated by the computed p-value greater than the 0.05 level of significance. The manner ALS is implemented is not influenced by their values development. 
The non-passers expressed their improvement in understanding themselves and digital citizenship but these are not because of the competencies of teachers nor by how well they were taught and how good were the materials used. They learned because learners which are mostly adult have a health of life experience and have already assumed responsible roles and more interested in learning that have immediate relevance and impact to their personal life. This notion made them think that taking the examination would be easy for them. Their failure may imply that it does not really capture what the learners are capable of. Some of them were doing well during the class sessions and successful in the class but still are not able to pass the test. Some said that examination anxiety, inappropriate study habits and inadequate preparation make a student fail. With this, a more authentic assessment to determine the qualification of taking the test is necessary (Villenes, 2014).

Table 21:- Problems Encountered by the Instructional Managers in the Implementation of ALS.

\begin{tabular}{|l|l|l|}
\hline Indicators & Mean & Rank \\
\hline $\begin{array}{l}\text { 1. The materials used in teaching ALS are not enough (e.g. } \\
\text { blackboard, pens, posters, etc.) }\end{array}$ & 3.00 & 10 \\
\hline $\begin{array}{l}\text { 2. The provision of professional growth and development for } \\
\text { ALS implementers and learners }\end{array}$ & 3.70 & 6.5 \\
\hline $\begin{array}{l}\text { 3. Open communication among staff and concerned people } \\
\text { among ALS implementers and learners }\end{array}$ & 3.80 & 3 \\
\hline $\begin{array}{l}\text { 4. Fairness of performance ratings rendered to ALS } \\
\text { implementers and learners }\end{array}$ & 3.80 & 3 \\
\hline 5. Sufficiency of benefits/compensation of ALS implementers & 3.40 \\
\hline $\begin{array}{l}\text { 6. Fund for the program that can be seen in the materials } \\
\text { provided for the program and manpower to accommodate } \\
\text { the needs of ALS learners }\end{array}$ & 3.40 \\
\hline $\begin{array}{l}\text { 7. The program monitoring and evaluation to assess how it is } \\
\text { Implemented }\end{array}$ & 8.5 \\
\hline $\begin{array}{l}\text { 8. The lessons to ensure that students will pass the } \\
\text { examination of ALS A and E }\end{array}$ & 3.80 \\
\hline 9. DepEd officials support in the implementation of ALS & 3.70 \\
\hline $\begin{array}{l}\text { 10. City and provincial government officials' support in the } \\
\text { program implementation of ALS }\end{array}$ & 3.80 \\
\hline \begin{tabular}{l} 
Table 21 shows the problems encount \\
\hline
\end{tabular} & 3.80 \\
\hline
\end{tabular}

Table 21 shows the problems encountered by the instructional managers in the implementation of the ALS Program in the City Division

The first two problems are related to instructional managers and the learners. It's true that instructional managers should maintain good relationship with the learners and lead them to learn. This often hinges on their attitude and ability to communicate at the learners' level. The teachers need to be flexible and understanding that no two learners are the same. Not all learners learn the same way at the same pace. Therefore, understanding each learner and monitoring one's performance are important (Villenes, 2014). On the other hand, the other three problems are related to ALS higher implementers support to the program. In this connection, Pinca (2015) [19] said the higher officials may consider review of policies to address or solve the problems that they encounter because the problems encountered by the students have implications to the services rendered by ALS.

Table 22:- Problems encountered by the A and E Passers and Non-Passers in the Implementation of ALS.

\begin{tabular}{|c|c|c|c|c|}
\hline \multirow[t]{2}{*}{ Indicators } & \multicolumn{2}{|c|}{ Passers } & \multicolumn{2}{|c|}{ Non-passers } \\
\hline & Mean & Rank & Mean & Rank \\
\hline $\begin{array}{l}\text { 1. The materials used in teaching ALS are not } \\
\text { enough (e.g. blackboard, pens, posters, etc.) }\end{array}$ & 2.80 & 10 & 2.56 & 10 \\
\hline $\begin{array}{l}\text { 2. The provision of professional growth and } \\
\text { development for ALS implementers and } \\
\text { learners }\end{array}$ & 3.11 & 7 & 3.26 & 7 \\
\hline $\begin{array}{l}\text { 3. Open communication among staff and } \\
\text { concerned people among ALS implementers } \\
\text { and learners }\end{array}$ & 3.31 & 4.5 & 3.41 & 4 \\
\hline 4. Fairness of performance ratings rendered to & 3.31 & 4.5 & 3.37 & 5 \\
\hline
\end{tabular}




\begin{tabular}{|l|l|l|l|l|}
\hline \multicolumn{1}{|c|}{ ALS implementers and learners } & & & & \\
\hline $\begin{array}{l}\text { 5. Sufficiency of benefits/compensation of ALS } \\
\text { Implementers }\end{array}$ & 3.17 & 6 & 3.34 & 6 \\
\hline $\begin{array}{l}\text { 6. Fund for the program that can be seen in the } \\
\text { materials provided for the program and } \\
\text { manpower to accommodate the needs of ALS } \\
\text { learners }\end{array}$ & 2.98 & 9 & 2.95 & 9 \\
\hline $\begin{array}{l}\text { 7. The program monitoring and evaluation to } \\
\text { assess how it is implemented }\end{array}$ & 3.02 & 8 & 3.21 & 8 \\
\hline $\begin{array}{l}\text { 8. The lessons to ensure that students will pass } \\
\text { the examination of ALS A and E }\end{array}$ & 3.37 & 2 & 3.50 & 1 \\
\hline $\begin{array}{l}\text { 9. DepEd officials support in the implementation } \\
\text { of ALS }\end{array}$ & 3.41 & 1 & 3.48 & 3 \\
\hline $\begin{array}{l}\text { 10. City and provincial government officials' } \\
\text { support in the program implementation of ALS }\end{array}$ & 3.36 & 3 & 3.49 & 2 \\
\hline
\end{tabular}

Table 23 displays the problems encountered by the ALS A\&E passers and non-passers in the implementation of ALS program. Passers and non-passers considered the same top three problems but on different order.

It implies that those are the things that bother them during their time. The DepEd Officials and City and Provincial Government Officials' support are not felt. They may have this idea because of their learning centers which are not as big as the formal education. Students attended the program in a community learning centers which are usually in barangay hall, church or any place provided for them in the community where they meet together. It was the instructional managers who tried to make the classrooms conducive for learning (Fernandez, 2014). According to Ebora and Guillo (2018), improving the quality of school facility creates satisfaction and reduces school stress among learners. Although, higher officials do not often visit the learning centers but when the learners are comfortable with the centers and have most of the learning materials they may say they can feel the government support.

\section{Conclusions and Recommendations:-}

The research found out that the methods of teaching are related to ALS passers' improvement in life and career skills and that community support influences their communication skills.

The learners' progress in reading and understanding newspapers and other reading materials both in English and in Filipino is related to the frequent support of the LGU. They may be inspired by these officials' continual visits or by their frequent encounter with them which enables them to practice their communication skills. It also implies that the methods of teaching influence how the students learn the life and career skills. The learners tend to remember skills which used practical examples.

Instructional Managers (IMs) and Mobile Teachers (MTs) are encouraged to undergo relevant trainings and workshop seminars regarding teaching approaches and pedagogies to enhance their classroom delivery of instruction in order to respond to the challenges of the 21 st Century and demands of the global arena.

Instructional Managers (IMs) and Mobile Teachers (MTs) may take appropriate steps to strengthen their instructional competence and come up with appropriate strategies to produce learners equipped with requisite life skills and steeped with values aligned to the learning strands of the program.

ALS implementers may establish linkages with possible stakeholders in the private sectors who can donate materials and can help in improving learning facilities. They may also consider partnering with universities and take advantage of their community extension services.

Learners may be provided with individual portfolio where weekly performance may be kept for reference.

ALS Education Program Specialists, through the Curriculum Implementation Division, may consider the reassessment and updating of ALS Program and Curriculum with addition of more relevant topics depicting 21st Century Skills and Competencies. They may produce modules that are A and E Test-skills-based, values-laden, 
localized and contextualized to help both IMS and learners ensure mastery of life skills and values development which may lead to an increased A and E passing rate.

The proposed program is recommended for implementation.

\section{Acknowledgement:-}

The authors would like to acknowledge the graduate school of the College of Teacher Education, Laguna State Polytechnic University, for the technical assistance provided for the completion of this study.

\section{References:-}

1. Republic Act 9155 - Governance of Basic Education Act of 2001

2. Bumanglag, Philip O. (2016) Formal Education Versus Alternative Learning System. The Modern Teacher, Volume 65, 132-133.

3. DepEd Order No. 13, s. 2019 - Policy Guidelines on the Implementation of Enhanced Alternative System 2.0 on June 25, 2019.

4. Jackson, Sherri L. (2015) Research Methods and Statistics, Acritical Thinking Approach, Fifth Edition

5. Abastilas Arvin T. (2018) Alternative Learning System Program at the Bureau of Jail Management and Penology in Region IV-A: An Enhanced Policy Formulation. Southern Luzon State University. Lucban, Quezon

6. Ebora, M. and Guillo, R. (2018).Comprehensive Management Plan for the Alternative Learning System in the Division of Batangas City. International Journal of Research, Vol 6 (4), 1 - 22.

7. Fernandez, R.M. (2014). Teachers' Competence and Learners' Performance in the Alternative Learning System Towards An Enriched Instructional Program . International Journal of Information Technology And Business Management, Vol.22 (1) .

8. Formento, A. (2011). Assessment of the Programs on Alternative Learning System in MIMAROPA Region.Unpublished Dissertation.Philippine Normal University.

9. Apao,L., Dayagbil, F.T. and Abao, E. L. (2014). Alternative Learning System Accreditation and Equivalency (ALS A\&E) Program: Quality of Life beyond Poverty. International Journal of Interdisciplinary Research and Innovations, Vol. 2(4), 20-26.

10. Pilar, J.G. (2015). Education Beyond Borders: Lived Experience in Teaching Basic English Grammar in ALS Teachers in Bacolod City Philippines. Asia Pacific Journal of Multidiciplinary Research, Vol 3 (4), 170- 178.

11. Guerrero, C. (2007). Country Profile Prepared for the Education for All Global Monitoring Report 2008 Education for All by 2015: will we make it? .UNESCO.

12. Kale, T. (2010). Non-Formal Education As A Means To Meet Learning Needs Of Out Of-school Children And Adolescents. Unesco.

13. Tangonan, O. (2012). Proposed Functional Program Design for Academe and Community Partnership in Alternative Learning System (ALS), Division of Calapan City, Oriental Mindoro.

14. Egcas, R. and Garganera, J. (2019).Impact of Alternative Learning System to the Out-of-School Youths, Kasambayan, Indigenous People and Children In-conflict-with-the-law. Asia Pacific Journal of Multidiciplinary Research, Vol 7 (3), $15-21$.

15. Atillano, E. B., Desipeda, C. J., Domingo , Z. J., Omanito, R. A., and Garbin, S. N. (2016). Factors Influencing The Dropout Rate In Alternative Learning System - Accreditation And Equivalency Program. The Online Journal of New Horizons in Education, Volume 6 (4),

16. Villenes, R. (2014). Factors Affecting the Achievements of Completers in Alternative Learning System (ALS) in the Province of Laguna.Unpublished Doctoral Dissertation.Philippine Normal University.

17. Lua, E. (2015). Non-Formal Education Among Out-of- School-Youth: Case Studies of Service Providers of the Philippines Alternative Learning System. Azusa Pacific University.

18. Mercado, I.P. (2015). Problems Encountered in the Alternative Learning System in Tanauan City. International Journal of Education and Social Science, Vol. 2 (8).

19. Pinca, E. C. (2015). The Mobile Teachers' Profile, Competencies, Performance and Problems In The Department Of Education, Division Of Northern Samar, Philippines .International Journal of Scientific \& Technology Research, Vol 4 (12). 